\title{
First report of interaction of nematophagous fungi on Libyostrongylus douglassii (Nematoda: Trichostrongylidae)
}

\author{
Primeiro relato da interação de fungos nematófagos sobre Libyostrongylus douglassii
}

(Nematoda: Trichostrongilidae)

\begin{abstract}
Fabio Ribeiro Braga ${ }^{1,2 *}$; Jackson Victor Araújo ${ }^{1}$; Alexandre de Oliveira Tavela ${ }^{1}$; Vinicius Longo Ribeiro Vilela ${ }^{4}$; Filippe Elias de Freitas Soares ${ }^{3}$; Juliana Milani Araujo ${ }^{1}$; Layane Queiroz Magalhães ${ }^{1}$; Wendeo Ferreira da Silveira ${ }^{1}$; Thais Ferreira Feitosa ${ }^{4}$; Elaine Silva Dantas ${ }^{4}$; Ana Célia Rodrigues Atahyde ${ }^{4}$
\end{abstract}

\author{
${ }^{1}$ Departamento de Veterinária, Universidade Federal de Viçosa - UFV, Viçosa, MG, Brasil \\ ${ }^{2}$ Universidade Vila Velha - UVV, Vila Velha, ES, Brasil \\ ${ }^{3}$ Departamento de Bioquímica e Biologia Molecular, Universidade Federal de Minas Gerais - UFMG, Belo Horizonte, MG, Brasil \\ ${ }^{4}$ Universidade de Campina Grande - UFCG, Patos, PB, Brasil
}

Received January 17, 2012

Accepted May 11, 2012

\begin{abstract}
Libyostrongylus douglassii is a gastrointestinal nematode parasite of ostriches that can cause up to $50 \%$ mortality in young birds. The objective of this study was to compare the predatory capacity of two isolates of the predatory fungi Duddingtonia flagrans (AC001 and CG722 isolates) and one of Arthrobotrys cladodes (CG719) on infective larvae ( $\mathrm{L}_{3}$ ) of $L$. douglassii under laboratory conditions, in $2 \%$ water-agar medium. The results showed that the fungi tested were effective in preying upon the $\mathrm{L}_{3}$ of $L$. douglassii $(\mathrm{P}<0.05)$, compared with the control group. However, there was no difference in predatory capacity between the fungi tested $(\mathrm{P}>0.05)$ during the seven days of experimental testing. In comparison with the control, without fungus, there were significant decreases $(\mathrm{P}<0.05)$ of $85.2 \%$ (AC001), 81.2\% (CG722) and 89.2\% (CG719) in the average numbers of $\mathrm{L}_{3}$ of $L$. douglassii recovered from treatments with the isolates tested. In the present study, the three isolates of the predatory fungi D. flagrans (AC001 and CG722) and A. cladodes (CG719) were efficient at in vitro destruction of the $\mathrm{L}_{3}$ of $L$. douglassii.
\end{abstract}

Keywords: Nematophagous fungi, Duddingtonia flagrans, Arthrobotrys cladodes, Libyostrongylus douglassii, Struthio camelus.

\section{Resumo}

Libyostrongylus douglassii é um nematóide parasito gastrintestinal de avestruzes que pode causar até $50 \%$ de mortalidade em aves jovens. O objetivo deste trabalho foi comparar a capacidade predatória de dois isolados de fungos predadores Duddingtonia flagrans (isolados AC001 e CG722) e um Arthrobotrys cladodes (CG719) sobre larvas infectantes $\left(\mathrm{L}_{3}\right)$ de $L$. douglassii em condiçóes laboratoriais, em meio ágar-água $2 \%$. Os resultados demonstraram que os fungos testados foram eficientes em predar as $\mathrm{L}_{3}$ de $L$. douglassii $(\mathrm{P}<0,05)$ em relação ao grupo controle. Contudo, não foi observada nenhuma diferença na capacidade predatória entre os fungos testados $(P>0,05)$ durante os sete dias do ensaio experimental. Em comparação ao controle, sem fungo, houve uma redução significativa ( $\mathrm{P}<0,05)$ de $85,2 \%$ (AC001); 81,2\% (CG722) e 89,2\% (C719) na média de $\mathrm{L}_{3}$ recuperadas nas placas do grupo tratado com os isolados testados. No presente trabalho, os três isolados de fungos predadores D. flagrans (AC001 e CG722) e A. cladodes (CG719) foram eficientes na destruição in vitro das $\mathrm{L}_{3}$ de L. douglassii.

Palavras-chave: Fungos nematófagos, Duddingtonia flagrans, Arthrobotrys cladodes, Libyostrongylus douglassii, Struthio camelus.

\footnotetext{
*Corresponding author: Fabio Ribeiro Braga

Departamento de Veterinária, Universidade Federal de Viçosa - UFV,

Av. Ph Rolf, s/n, CEP 36570-000, Viçosa, MG, Brasil

e-mail: fabioribeirobraga@hotmail.com
} 
Ostriches (Struthio camelus) are poultry belonging to the ratite group. These birds present diurnal activity; they are reared in groups when young and for slaughter, and in couples or trios when used for reproduction (AICHINGER et al., 2007). The main breeds commercialized are African Black, Red Neck and Blue Neck. Among these, the one of greatest commercial importance is the African Black (S. camelus var. domesticus). Currently, the countries that are the greatest breeders of ostriches are: South Africa, Israel, Australia, Canada, United States, Italy, Spain, France and China (CARRER, 2004). In Brazil specifically, commercial rearing of ostriches is gaining greater economic importance due to the birds' good environmental adaptation and, in particular, the potential for profitability. On the other hand, a variety of species may parasitize ostriches (CARRER, 2004; VIEIRA-DA-MOTTA et al., 2008).

Nematodes of the genus Libyostrongylus ( $L$. douglassii, L. dentatus and L. magnus), belonging to the family Trichostrongylidae, are hematophagous and therefore are considered to be pathogenic towards ostriches. The disease caused by these nematodes causes rotting of the stomach, and is known as "vrotmaag" in South Africa, where it is responsible for the mortality of more than $50 \%$ of juvenile ostriches (REINECKE, 1983). L. douglassii is considered to be the most pathogenic species and is the main parasite of ostriches in the tropics (THEILER, 1915; HOBERG et al., 1995; MacKRETH, 2004). Well-nourished adult ostriches can maintain high parasite loads with no clinical signs (BARTON; SEWARD, 1993), and are able to live in this way for many years. McKenna (2005) also mentioned that on farms where this nematode is present, the young poultry should be kept away from adults and from infected pastures; however, the $\mathrm{L}_{3}$ can be present in pastures for long periods.

In this context, use of nematophagous fungi, especially of the genera Arthrobotrys and Duddingtonia, which have the capacity to destroy $\mathrm{L}_{3}$ present in the external environment, has been shown to be effective when administered orally to domestic animals that are kept with a focus on production, as well as in tests under laboratory conditions (BRAGA et al., 2009; SILVA et al., 2010; TAVELA et al., 2011). However, there are no reports in the literature on interactions between these fungi and gastrointestinal nematode parasites of ostriches.

Three isolates of nematophagous fungi, two of $D$. flagrans (AC001 and CG722) and one of Arthrobotrys cladodes (CG719), were used. These isolates originally came from soil in the city of Viçosa, Brazil, and have been maintained through continuous transfer to solid culture media in the Department of Veterinary Medicine, Federal University of Viçosa, Brazil.

Culture disks of $4 \mathrm{~mm}$ in diameter were extracted from fungal isolates kept in test tubes containing 2\% cornmeal agar (2\% CMA) and transferred to Petri dishes of $9.0 \mathrm{~cm}$ in diameter containing $20 \mathrm{~mL}$ of $2 \%$ potato dextrose agar, which were than kept at $25^{\circ} \mathrm{C}$ in the dark for 10 days. After the growth of the isolates, new culture disks of $4 \mathrm{~mm}$ in diameter were transferred to Petri dishes of $9.0 \mathrm{~cm}$ diameter containing $20 \mathrm{~mL}$ of $2 \%$ water agar (2\% WA). Following this, $1 \mathrm{~mL}$ of distilled water containing 1000 larvae of Panagrellus sp. was added to these dishes daily over a 21-day period, to induce formation of fungal conidia. When complete fungal development was observed, $5 \mathrm{~mL}$ of distilled water were added to each Petri dish, and the conidia and mycelial fragments were removed using the technique described by Araújo et al. (1993).

Females of adult helminths of the genus Libyostrongylus were recovered from a naturally infected 36-month-old male ostrich, during an autopsy at the Federal University of Campina Grande, Paraíba, Brazil. Then, after retrieval, the females were identified as belonging to the species L. douglassii, based on the following morphological characters: ovijector length, total body length and presence or absence of cuticular swelling at the level of the anus and of a prominent esophageal tooth (HOBERG et al., 1995; EDERLI et al., 2008). The females of $L$. douglassii were then macerated and distributed into five cups containing $20 \mathrm{~g}$ of sterilized feces from sheep together with vermiculite, and the larvae were cultured in accordance with Roberts et al. (1952) and then placed in an incubation chamber at $28^{\circ} \mathrm{C}$ for 10 days. Subsequently, the $\mathrm{L}_{3}$ were recovered in accordance with the Baermann technique (LIMA, 1989). The tube contents were homogenized and three aliquots of $10 \mu \mathrm{L}$ were removed from it and distributed across a glass plate measuring $7.5 \times 2.5 \mathrm{~cm}$. The larvae were counted with the assistance of a stereomicroscope at a magnification of $25 x$.

Four groups were formed in Petri dishes of $9.0 \mathrm{~cm}$ in diameter containing $20 \mathrm{~mL}$ of $2 \%$ WA: three treated groups and one control group. Six repetitions were made for each group. The Petri dishes were marked out with fields of $4 \mathrm{~mm}$ in diameter. In the treated groups, each Petri dish contained $500 \mathrm{~L}_{3}$ of $L$. douglassii and 500 conidia of the fungal isolates AC001, CG722 and CG719, respectively, in 2\% WA. The control group (without fungi) only contained $500 \mathrm{~L}_{3}$ in the plates, with $2 \%$ WA (MOTA et al., 2002).

For seven days, after every 24 hours, 10 random fields of $4 \mathrm{~mm}$ in diameter on each plate of the treated and control groups were observed under an optical microscope with a $10 \times$ objective. The number of $\mathrm{L}_{3}$ that had not been preyed on was counted on each dish. After seven days, the non-preyed $\mathrm{L}_{3}$ were recovered from the content of the Petri dishes using the Baermann apparatus with water at $42{ }^{\circ} \mathrm{C}$ (BRAGA et al., 2010).

The mean number of $\mathrm{L}_{3}$ of $L$. douglassii recovered was calculated. The data were interpreted statistically by means of variance analysis, at significance levels of $1 \%$ and $5 \%$ probability (AYRES et al., 2003). The efficiency of predation of $\mathrm{L}_{3}$ compared with the control was assessed using Tukey's test at $1 \%$ and $5 \%$ probability. Subsequently, the average percentage reduction of $\mathrm{L}_{3}$ was calculated in accordance with the following formula:

$$
\% \text { reduction }=\left(\begin{array}{c}
\begin{array}{c}
\text { mean number of } \mathrm{L}_{3} \\
\text { recovered from control }
\end{array} \\
\hline \text { mean number of } \mathrm{L}_{3} \text { recovered from control }
\end{array}\right) \times 100
$$

In the present study, the isolates of nematode-predatory fungi that were tested, i.e. D. flagrans (AC001 or CG722) and A. robusta (CG719), were able to prey on the $\mathrm{L}_{3}$ of $L$. douglassii in the experimental assay in vitro. On the other hand, comparing the capture and destruction of $\mathrm{L}_{3}$ in Petri dishes between the groups treated with the isolates tested, there was no statistical difference ( $p>0.01$ ) (Table 1). After 24 hours, it was also observed that the fungi AC001, CG722 and CG719 produced traps in the Petri dishes, thereby causing destruction of the $\mathrm{L}_{3}$. In this regard, the following percentage reductions of $\mathrm{L}_{3}$ were observed: $85.2 \%$ (AC001), 81.2\% (CG722) and 89.2\% (CG719). 
Table 1. Daily means and standard deviations of non-predated third stage larvae $\left(\mathrm{L}_{3}\right)$ of Libyostrongylus douglassii per 4 mm diameter field in 2\% water agar over a seven-day period, in treatments with the fungus isolates Duddingtonia flagrans (AC001 and CG722) and Arthrobotrys cladodes (CG719) and a control without fungus.

\begin{tabular}{cccccrcr}
\hline \multirow{2}{*}{ Fungi } & \multicolumn{7}{c}{ Time (Days) } \\
\cline { 2 - 8 } & \multicolumn{1}{c}{$\mathbf{1}$} & $\mathbf{2}$ & $\mathbf{3}$ & $\mathbf{4}$ & $\mathbf{5}$ & $\mathbf{6}$ \\
\hline $\mathrm{AC} 001$ & $9.2^{\mathrm{A}} \pm 9.1$ & $7.6^{\mathrm{A}} \pm 6.3$ & $5.7^{\mathrm{A}} \pm 4.1$ & $4.8^{\mathrm{A}} \pm 3.9$ & $2.9^{\mathrm{A}} \pm 4.1$ & $1.9^{\mathrm{A}} \pm 3.2$ & $1.4^{\mathrm{A}} \pm 3.3$ \\
CG722 & $11.1^{\mathrm{A}} \pm 10$ & $9.5^{\mathrm{A}} \pm 8.9$ & $7.2^{\mathrm{A}} \pm 6.4$ & $5.3^{\mathrm{A}} \pm 4.7$ & $4.9^{\mathrm{A}} \pm 3.8$ & $4.6^{\mathrm{A}} \pm 3.8$ & $2.4^{\mathrm{A}} \pm 3.5^{\mathrm{A}}$ \\
CG719 & $11.9^{\mathrm{A}} \pm 9.6$ & $10.4^{\mathrm{A}} \pm 12$ & $7.7^{\mathrm{A}} \pm 7.1$ & $6.6^{\mathrm{A}} \pm 5.1$ & $5.4^{\mathrm{A}} \pm 5.2$ & $4.8^{\mathrm{A}} \pm 3.7$ & $2.6^{\mathrm{A}} \pm 4.2$ \\
Control & $22^{\mathrm{B}} \pm 13.2$ & $18.1^{\mathrm{B}} \pm 9.4$ & $17^{\mathrm{B}} \pm 8.3$ & $15.6^{\mathrm{B}} \pm 7.4$ & $14.4^{\mathrm{B}} \pm 8.3$ & $13^{\mathrm{B}} \pm 5.8$ & $11.0^{\mathrm{B}} \pm 5.0$ \\
\hline
\end{tabular}

Means followed by the same small letter in the lines were not statistically different $(\mathrm{p}>0.01)$.
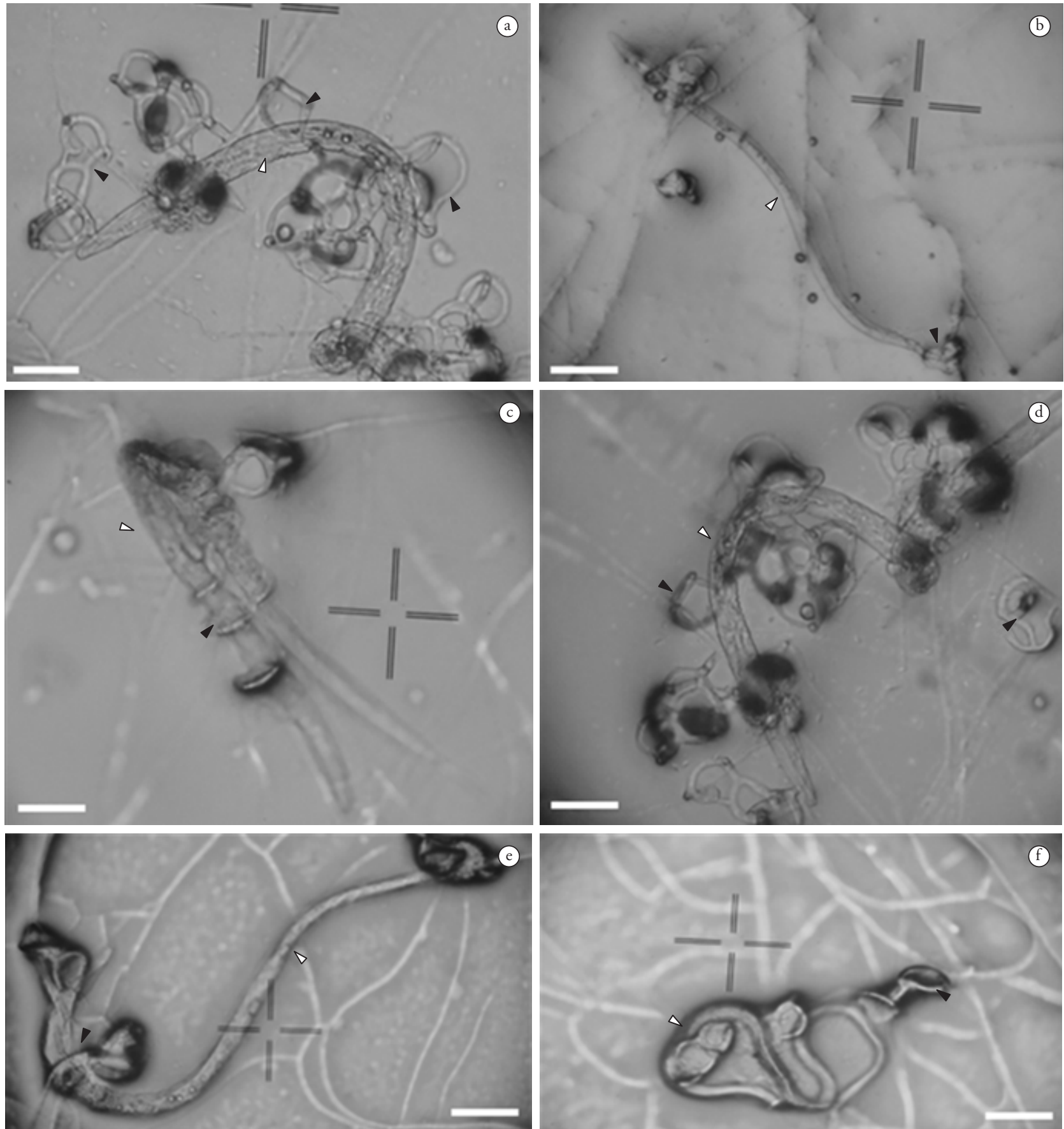

Figure 1. a-f. Infective larvae $\left(\mathrm{L}_{3}\right)$ of Libyostrongylus douglassii captured by nematophagous fungi (white arrow) in Petri dishes containing $2 \%$ water agar, and trap formation by the fungal isolates (black arrow). Bars: a) $138.3 \mu \mathrm{m}$; b) $150 \mu \mathrm{m}$; c) $83 \mu \mathrm{m}$; d) $140 \mu \mathrm{m}$; e) $127.6 \mu \mathrm{m}$ and f) $237.1 \mu \mathrm{m}$. 


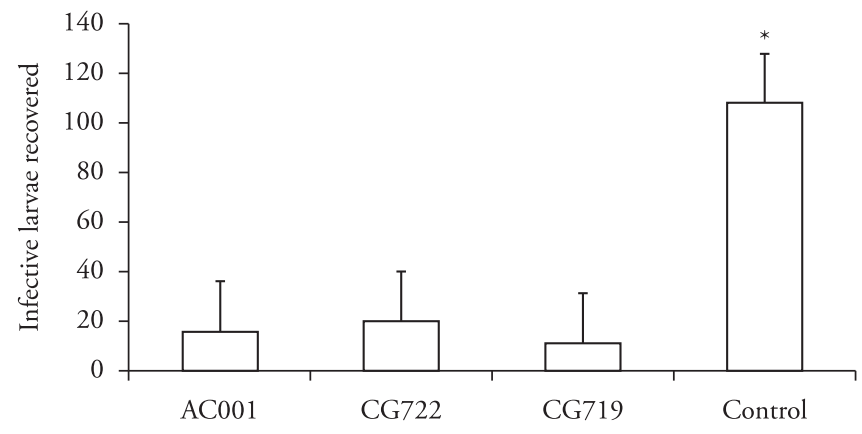

Figure 2. Means and standard deviation (bars) of infective non-predated Libyostrongylus douglassii larvae recovered from 2\% water agar plates using the Baermann method on the seventh day of treatment with the following fungal isolates: Duddingtonia flagrans (AC001 and CG722) and Arthrobotrys cladodes (CG719); and a control group (without fungi). Asterisk denotes significant difference $(\mathrm{p}<0.05)$ between the fungus-treated group and the control: Tukey's test at $1 \%$ probability level.

A difference $(\mathrm{p}<0.05)$ was observed in the mean number of $\mathrm{L}_{3}$ of $L$. douglassii not preyed on per field of $4 \mathrm{~mm}$ in diameter on the plates of the control group, in relation to the mean number of $\mathrm{L}_{3}$ registered on the plates of the groups treated with fungi, throughout the experiment (Figure 1). Regarding the plates of the control group, no nematophagous fungi were present at any time during the experiment. However, the presence of $\mathrm{L}_{3}$ of $L$. douglassii in Petri dishes containing 2\% WA was essential for the formation of traps by the fungal isolates. Evidence of predation was verified through the number of $\mathrm{L}_{3}$ of $L$. douglassii recovered on the seventh day using the Baermann method, at the end of the experiment (Figure 2), which showed that there was a difference $(\mathrm{p}<0.01)$ between the number of $\mathrm{L}_{3}$ recovered from the fungal treatments and the number from the control.

There are few studies about parasitoses that infect ostriches. Nonetheless, a wide variety of parasites can focus on these birds, especially L. douglassii, which causes direct damage to the ostrich development, due to the high mortality caused among young birds (EDERLI, 2009). L. douglassii is considered to be resistant to environmental changes and to temperature extremes (JANSSON et al., 2002). In this context, the presence of nematodetrapping fungi in the environment could be an alternative control method that would directly assist in reducing recurrent infections (BRAGA et al., 2010; FERREIRA et al., 2011). This is corroborated by the present study, since the three fungal isolates tested (AC001, CG722 and CG719) in the experimental assay were efficient at capture and destruction of $\mathrm{L}_{3}$ (Figure 1). This is the first study on the interaction of the fungi D. flagrans (AC001 and CG722) and A. cladodes (CG719) on $\mathrm{L}_{3}$ of L. douglassii. Moreover, few papers have mentioned the predatory activity in vitro of different nematophagous fungi on infective forms (or eggs and larvae) of nematode parasites of birds (BRAGA et al., 2011, 2012).

According Araújo et al. (2004), the biological control achieved with these fungi has been shown to be effective under both laboratory and natural conditions, since it is practiced in an inundative manner. In this regard, Braga et al. (2009) showed that after six months, orally administered D. flagrans (AC001) had reduced the egg count per gram of feces (EPG) from naturally infected horses by a mean of
$46.2 \%$, in relation to the animals in the control group. Furthermore, that study also showed that the treated animals had better weight gain (12.1\% better) than shown by the control group at the end of the experiment. Compared with the present study, some questions may be raised, including the following: (1) in general, the larvae of gastrointestinal nematode parasites and in particular Trichostrongylidae are resistant and remain in pastures throughout the year, and this premise is also valid for L. douglassii, i.e. the ostrich trichostrongylid; (2) with a lower parasite load, there will probably be better feed conversion and greater control over mortality, especially among young animals. In the context of the present study, well-nourished adult ostriches are able to maintain high parasite load, while remaining asymptomatic (BARTON; SEWARD, 1993). Moreover, it needs to be borne in mind that a single infected ostrich that is apparently healthy can eliminate approximately 3.5 million eggs of Libyostrongylus spp. per day. In this specific case, environmental control implemented using D. flagrans and A. cladodes could constitute a further control tool, since their action focuses directly on infective forms present in the fecal matter.

Generally, the most practical use of nematophagous fungi is in oral administration of fungal material (mycelium, conidia and chlamydospores) to domestic animals. On the other hand, there has been discussion in the literature suggesting that use of different isolates of the same fungus at different concentrations may have different results (ARAÚJO et al., 1993). In a recent study, Braga et al. (2011) showed that two isolates of D. flagrans (AC001 and CG722) were equally effective $(P>0.01)$ in reduction in vitro of cyathostomin larvae (nematodes of horses), after treatment with conidia on interval of seven days. On that occasion, the authors demonstrated percentage reductions of $88.6 \%$ and $78.4 \%$ through using the fungi, respectively. At the level of comparison with other work, Carvalho et al. (2009) showed that the fungus A. cladodes (CG719) was effective in reducing Ancylostoma caninum $\mathrm{L}_{3}$ (a nematode of dogs), with a reduction of $76.9 \%$ in comparison with other predatory fungi that were used, at the end of the experiment. Although those results are concordant with the present study, it needs to be remembered that because of the lack of studies on the gastrointestinal nematodes of birds, it becomes difficult to make other comparisons. However, we emphasize that this information justifies use of nematophagous predatory fungi in environmental control of $\mathrm{L}_{3}$ in domestic animals.

However, among the factors that stand out regarding the spread of nematodes in ostriches are the following: (1) the direct life cycle of the parasite; (2) inadequate management in rearing these birds; (3) failures in parasite control; and (4) trade without prior knowledge of parasitism (PONCE GORDO et al., 2002). Thus, from the results of the present study over a seven-day period (Table 1) and at the end of the experimental period (Figure 2), we suggest that future research within this field should be directed towards oral administration of predatory nematophagous fungi among naturally infected ostriches that are reared on pasture, which could potentially contribute towards controlling $\mathrm{L}_{3}$ of $\mathrm{L}$. douglassii that is present in pastures.

\section{Acknowledgements}

The authors thank, CNPq, CAPES and FAPEMIG for their financial support. 


\section{References}

Aichinger A, Martins NR, Souza JD, Resende JS, Muniz R, Ferreira WM. O avestruz no Brasil e no mundo. Rev Vet Zootec Minas 2007; 27(95): 36-39.

Araújo JV, Santos MA, Ferraz S, Maia AS. Antagonistic effect of predacious Arthrobotrys fungi on infective Haemonchus placei larvae. J Helminthol 1993; 67(2): 136-138. PMid:8354858. http://dx.doi. org/10.1017/S0022149X00013018

Araújo JV, Mota MA, Campos AK. Controle biológico de helmintos de animais por fungos nematófagos. Rev Bras Parasitol Vet 2004; 13(S1): 165-170.

Ayres M, Ayres JRM, Ayres DL, Santos AS. Aplicaçôes estatísticas nas áreas de ciências biológicas e médicas. Belém: Sociedade Civil Mamirauá; Brasília CNPq; 2003. p. 290.

Barton NJ, Seward DA. Detection of Libyostrongylus douglassii in ostriches in Australia. Aust Vet Journal 1993; 70(1):31-32. PMid:8460985. http:// dx.doi.org/10.1111/j.1751-0813.1993.tb00796.x

Braga FR, Araújo JV, Araujo JM, Frassy LN, Tavela AO, Soares FEF, et al. Pochonia chlamydosporia fungal activity in a solid medium and its crude extract against eggs of Ascaridia galli. J Helminthol 2012; 86(3): 348-352. PMid:21838959. http://dx.doi.org/10.1017/S0022149X11000484

Braga FR, Araújo JV, Araujo JM, Tavela AO, Ferreira SR, Soares $\mathrm{FEF}$, et al. Influence of the preservation period in silica-gel on the predatory activity of the isolates of Duddingtonia flagrans on infective larvae of cyathostomins (Nematoda: Cyathostominae). Exp Parasitol 2011; 128(4): 460-463. PMid:21627962. http://dx.doi. org/10.1016/j.exppara.2011.05.013

Braga FR, Araújo JV, Silva AR, Carvalho RO, Araujo JM, Ferreira SR, et al. Predatory activity of the nematophagous fungus Duddingtonia flagrans on horse cyathostomin infective larvae. Trop Anim Health Prod 2010; 42 (6): 1161-1163. PMid:20213221. http://dx.doi. org/10.1007/s11250-010-9542-1

Braga FR, Araújo JV, Silva AR, Araujo JM, Carvalho RO, Tavela $\mathrm{AO}$, et al. Biological control of horse cyathostomin (Nematoda: Cyathostominae) using the nematophagous fungus Duddingtonia flagrans in tropical southeastern Brazil. Vet Parasitol 2009; 163(4): 335-340. PMid:19497672. http://dx.doi.org/10.1016/j.vetpar.2009.05.003

Carvalho RO, Araújo JV, Braga FR, Araujo JM, Silva AR, Tavela AO. Predatory activity of nematophagous fungi on infective larvae of Ancylostoma sp.: evaluation in vitro and after passing through gastrointestinal tract of dogs. J Helminthol 2009; 83(3): 231-236. PMid:19144215. http://dx.doi.org/10.1017/S0022149X08158965

Carrer CC. O mercado de avestruzes no Brasil e no mundo. Struthio Cult 2004; 3: 14-15.

Ederli NB. Caracterização morfológica de larvas infectantes de Libyostrongylus douglassii e Libyostrongylus dentatus (Nematoda, Trichostrongylidae) e adultos de Codiostomum struthionis (Nematoda, Strongylidae) parasitas de avestruzes, Struthio camelus [Dissertaçáo]. Rio de Janeiro: Universidade Federal Rural do Rio de Janeiro; 2009.

Ederli NB, Bonadiman SF, Moraes Neto AHA, DaMatta RA, Santos CP. Mixed infection by Libyostrongylus douglassii and L. dentatus (Nematoda: Trichostrongylidae) in Struthio camelus (Ratites: Struthioniformes) from Brazil with further morphological characterization of adults. Vet Parasitol 2008; 151(2-4): 227-232. PMid:18155840. http://dx.doi. org/10.1016/j.vetpar.2007.11.009
Ferreira SR, Araújo JV, Braga FR, Araujo JM, Fernandes FM. In vitro predatory activity of nematophagous fungi Duddingtonia flagrans on infective larvae of Oesophagostomum spp. after passing through gastrointestinal tract of pigs. Trop Anim Health Prod 2011; 43(8): 1589-1593. PMid:21626065. http://dx.doi. org/10.1007/s11250-011-9848-7

Hoberg EP, Lloyd S, Omar H. Libyostrongylus dentatus n.sp. (Nematoda: Trichostrongylidae) from ostriches in North America, with comments on the genera Libyostrongylus and Paralibyostrongylus. J Parasitol 1995; 81(1): 85-93. PMid:7876985. http://dx.doi. org/10.2307/3284011

Jansson DS, Christensson DA, Christensson BE. Winter survival in Sweden of L3-stage larvae of the ostrich wireworm Libyostrongylus douglassii. Vet Parasitol 2002; 106(1): 69-74. http://dx.doi.org/10.1016/ S0304-4017(02)00033-X

Lima WS. Dinâmica de populaçôes de nematóides gastrointestinais em bovinos de corte: alguns aspectos da relação parasito-hospedeiro e do comportamento dos estádios de vida livre na região do Vale do Rio Doce- MG, Brasil [Tese]. Belo Horizonte: Universidade Federal de Minas gerais; 1989.

MacKreth GF. Libyostrongylus douglassii in New Zealand ostriches. Surveillance 2004; 31(3): 14-16.

McKenna PB. Libyostrongylus infections in ostriches - a brief review with particular reference to their detection in New Zealand. $N$ $Z$ Vet J 2005; 53 (5): 267-270. PMid:16220116. http://dx.doi. org/10.1080/00480169.2005.36559

Mota MA, Campos AK, Araújo JV. Avaliação da capacidade predatória dos fungos Arthrobotrys robusta e Monacrosporium thaumasium sobre nematóides gastrintestinais parasitos de bovinos, submetidos a diferentes métodos de preservação. Rev Bras Parasitol Vet 2002; 11(1): 13-17.

Ponce Gordo F, Herrera S, Castro AT, García Durán B, Martínez Díaz RA. Parasites from farmed ostriches (Struthio camelus) and rheas (Rhea americana) in Europe. Vet Parasitol 2002; 107(1-2): 137-160. http:// dx.doi.org/10.1016/S0304-4017(02)00104-8

Reinecke RK. Vet Helminthol. Durban: Butterworth; 1983. p. 295.

Roberts FHS, O'Sullivan PJ, Riek RF. The epidemiology of parasitic gastro-enteritis of cattle. Aust J Agricult Res 1952; 3(2):187-226. http:// dx.doi.org/10.1071/AR9520187

Silva BF, Mauad JRC, Braga FR, Araújo JV, Campos AK, Amarante AFT. Efficacy of Duddingtonia flagrans and Arthrobotrys robusta in controlling sheep parasitic gastroenteritis. Parasitol Res 2010; 106(6): 1343-1350. PMid:20237801. http://dx.doi.org/10.1007/s00436-010-1805-2

Tavela AO, Araújo JV, Braga FR, Silva AR, Carvalho RO, Araujo JM, et al. Biological control of cyathostomin (Nematoda: Cyathostominae) with nematophagous fungus Monacrosporium thaumasium in tropical southeastern Brazil. Vet Parasitol 2011; 175 (1-2): 92-96. PMid:21035270. http://dx.doi.org/10.1016/j.vetpar.2010.09.035

Theiler A, Robertson W. Investigations into life-history of the wire-worm in ostriches. Reports of the Director of Veterinary Research, Union of South Africa. Depart Agricult 1915; (3-4): 291-346.

Vieira-da-Motta LS, Silveira LS, Teixeira GN, Cardinot CB, Lemos LS, Silva RST, et al. Diagnóstico microbiológico e histopatológico de mortalidade em avestruzes (Struthio camelus). Arq Bras Med Vet Zootec 2008; 60(4): 1014-1016. http://dx.doi.org/10.1590/S010209352008000400034 